\title{
$\int$ erRATUM
}

In the paper "Work centrality, goals and professional fulfillment: Intersections between work and career", published in Revista de Administração Mackenzie - RAM (Mackenzie Management Review), 20(1), eRAMG190087:

- At page 1, it should be read "LÍGIA C. OLIVEIRA-SILVA" instead of "LÍGIA C. O. SILVA".

- At page 1, it should be read in To cite this paper: "Moura, A. O. R., \& Oliveira-Silva, L. C. (2019)" instead of "Moura, A. O. R., \& Silva, L. C. O. (2019)".

- At page 25, it should be read in About the authors: "Aléxia O. R. Moura, Department of Organizational and Work Psychology, Universidade Federal de Uberlândia (UFU); \& Lígia C. Oliveira-Silva, Department of Social and Work Psychology, Universidade de Brasília (UnB). Aléxia O. R. Moura is now Human Resources Analyst at Sankhya Gestão de Negócios; \& Lígia C. Oliveira-Silva is now Adjunct Professor at Department of Organizational and Work Psychology at Universidade Federal de Uberlândia (UFU)." instead of "Aléxia O. R. Moura, Department of Organizational and Work Psychology, Universidade Federal de Uberlândia (UFU); \& Lígia C. O. Silva, Department of Social and Work Psychology, Universidade de Brasília (UnB). Aléxia O. R. Moura is now Human Resources Analyst, Department of Organizational and Work Psychology, Universidade Federal de Uberlândia (UFU); \& Lígia C. O. Silva is now Adjunct Professor at Department of Organizational and Work Psychology at Universidade Federal de Uberlândia (UFU)." 